\title{
PENGGUNAAN PENANDA GENETIK TUMBUH CEPAT UNTUK PRODUKSI CALON INDUK KERAPU SUNU, Plectropomus leopardus DALAM PROGRAM SELEKSI
}

\author{
Sari Budi Moria Sembiring, Haryanti, Ketut Suwirya, Ida Komang Wardana, \\ Tatam Sutarmat, dan Hirmawan Tirta Yudha \\ Balai Besar Penelitian dan Pengembangan Budidaya Laut \\ J. Br. Gondol Kec. Gerokgak Kab. Buleleng, Kotak Pos 140, Singaraja- Bali 81101 \\ E-mail: moriasembiring@yahoo.co.id
}

(Naskah diterima: 9 Agustus 2011; Disetujui publikasi: 16 Maret 2012)

\begin{abstract}
ABSTRAK
Penurunan kualitas benih kerapu seringkali diindikasikan dengan pertumbuhan yang lambat, rentan terhadap infeksi penyakit, dan perubahan lingkungan serta terjadinya abnormalitas. Upaya perbaikan sifat genetik benih kerapu akan memberikan dampak signifikan dalam keberhasilan budidaya. Tujuan penelitian ini adalah untuk memperoleh penanda gen tumbuh cepat pada benih/calon induk kerapu sunu sehingga dapat meningkatkan efisiensi dan efektivitas pemuliaan. Untuk mendapatkan penciri gen tumbuh cepat digunakan metode analisis mikrosatelit (SSR/Simple Sequence Repeats) dengan mengaplikasikan enam set primer (forward dan reverse). Calon induk yang digunakan untuk analisis masing-masing berjumlah 4 ekor ukuran kecil dan 10 ekor ukuran besar. Validasi dan akurasi lokus yang dihasilkan dianalisis lebih lanjut dengan sequencing. Hasil yang diperoleh menunjukkan bahwa penanda gen tumbuh cepat dapat terlihat dari lokus PL- 03 dengan alel/fragmen DNA pada berat molekul $370 \mathrm{bp}$. Tingkat keakuratan penanda gen tersebut pada kelompok ukuran besar mencapai $80 \%$ sedangkan pada kelompok ukuran kecil hanya 30\% Hal ini juga didukung dengan keakuratan prediksi dari hasil sequencing memberikan nilai kemiripan sebesar $99 \%$ Dengan demikian lokus PL-03 dapat digunakan sebagai penanda gen tumbuh cepat pada ikan kerapu sunu dalam mempercepat seleksi calon induk.
\end{abstract}

KATA KUNCI: penanda genetik, pertumbuhan cepat, mikrosatelit, selective breeding

ABSTRACT: Determination of genetic marker for fast growth in produce candidates broodstock of coral trout grouper, Plectropomus leopardus by selective breeding. By: Sari Budi Moria Sembiring, Haryanti, Ketut Suwirya, Ida Komang Wardana, Tatam Sutarmat, and Hirmawan Tirta Yudha

Reduction of fry quality frequently indicated by slow growth, susceptible disease infection and environmental fluctuation and increased of abnormality of juvenile. The effort to improve genetic quality of fish fry will give significant impact on successfully of grouper culture. The aim of this experiment was to find genetic marker for fast growth in order to get fry or candidate broodstock of coral trout which phenotype and genetically better and also to increase efficiency and effectiveness of selective breeding. To get fast growth marker, microsatellite analysis (SSR/Simple Sequence Repeats) method was applied with six set of primers forward and reverse. Samples of candidate broodstock were used to analyze i.e. 4 and 10 fishes for small and big size group respectively. To validate and accurate of loci produced, further analyzed by 
sequencing was conducted. The results showed that fast growth marker was found in loci PL-03 at DNA allele/fragment with molecule weight of $370 \mathrm{bp}$. The accuracy of this genetic marker for big size group of candidate broodstock was $80 \%$ while on small size group only $30 \%$. This result was fit to sequencing prediction which gave similarity value of $99 \%$ mean that loci PL-03 is good to apply as fast growth genetic marker for coral trout candidate broodstock selection.

\section{KEYWORDS: genetic marker, fast growth, microsatellite, selective breeding}

\section{PENDAHULUAN}

Kerapu merupakan komoditas ikan laut yang mempunyai nilai ekonomi tinggi dan mempunyai potensi pasar yang cukup besar di dunia. Salah satu di antara kerapu yang dibudidayakan adalah kerapu sunu, Plectropomus leopardus. Balai Besar Penelitian dan Pengembangan Budidaya Laut Gondol- Bali sudah berhasil mengembangkan pembenihan kerapu sunu hingga menghasilkan benih dengan ukuran yang sesuai untuk budidaya. Walaupun demikian, produksi benih belum stabil oleh karena sintasan yang masih berfluktuasi.

Keberhasilan perbenihan ikan kerapu sunu di hatcheri sangat dipengaruhi oleh kondisi lingkungan (suhu, salinitas, variasi pakan, kandungan nutrisi, kepadatan larva) infeksi penyakit dan karakter genetik, sehingga akan dihasilkan kualitas benih yang bervariasi. Berdasarkan beberapa hasil penelitian menunjukkan bahwa peran sifat genetik sangat berpengaruh pada kualitas benih sehingga berdampak pada pertumbuhan, sintasan, ketahanan terhadap penyakit, dan perubahan lingkungan. Oleh karena itu, peranan sifat genetik sangat penting untuk memperoleh induk dan benih yang unggul (Benzie et al., 1997; Sbordoni et al., 1987).

Teknologi pemuliaan melalui seleksi konvensional telah terbukti berhasil meningkatkan produksi, namun seleksi konvensional tersebut memiliki keterbatasan terutama dalam hal waktu yang diperlukan relatif lama untuk memunculkan gen- gen yang diinginkan. Salah satu kebutuhan dasar di dalam program pemuliaan adalah mendapatkan cara menyeleksi dalam jumlah sangat banyak, dalam waktu yang singkat dan pada fase awal pertumbuhan. Seleksi berdasarkan fenotipik seringkali memberikan hal yang tidak akurat, karena performansi fenotip banyak dipengaruhi oleh faktor lingkungan. Dengan demikian penggunaan penanda molekular harus dikembangkan. Pemanfaatan penanda molekular sebagai alat bantu seleksi pada program pemuliaan di Indonesia masih sangat sedikit dibandingkan dengan pemuliaan secara konvensional.

Seiring dengan semakin berkembangnya teknologi yang berbasis penanda DNA maka penanda mikrosatelit merupakan penanda molekular yang berkembang lebih akhir. Prinsip dasar penanda mikrosatelit adalah amplifikasi sekuen DNA tertentu menggunakan PCR dan umumnya salah satu primer diberi label supaya mempermudah deteksi (Fishback et al., 1999). Kelebihan utama penanda mikrosatelit terletak pada sifat polimorfisme dan daya pembedanya yang tinggi. Sifat tersebut dapat dikembangkan sebagai alat identifikasi genotip (Hancock, 1999).

Penggunaan penanda mikrosatelit telah dilaporkan pada beberapa jenis ikan seperti Hypopthgalmichthys militrix, Aphyocypris chinensis, Thunnus thynnus thynnus, dan Atlantik salmon (Slettan et al., 1993) serta leopard coral grouper (Plectropomus leopardus) (Xiong Ding et al., 2009). Penanda mikrosatelit juga telah digunakan dalam studi hubungan antara heterosigositas terhadap parameter pertumbuhan seperti pada ikan nila, Oreochromis niloticus (Appleyard et al., 2001), jenis kerang coklat, Mytilus edulis (Del RioPortilla \& Beaumont, 2000) dan udang P. stylirostris (Bierne et al., 2000).

Pemanfaatan penanda molekular dengan mengutamakan karakter kuantitatif tumbuh cepat dengan penciri gen bertujuan untuk memperbaiki kualitas genetik benih sehingga didapatkan benih/calon induk kerapu sunu dengan sifat fenotip dan genotip yang lebih baik dan juga untuk meningkatkan efisiensi dan efektivitas pemuliaan.

\section{BAHAN DAN METODE}

\section{Hewan Uji}

Jumlah sampel ikan kerapu sunu yang dianalisis sebanyak 14 ekor terdiri atas 4 ekor 
kelompok ukuran kecil dan 10 ekor kelompok ukuran besar. Kelompok ukuran kecil mempunyai panjang dan bobot rata- rata $13,95 \mathrm{~cm}$ dan 46,14 g sedangkan kelompok ukuran besar 25,5 cm dan 248,2 g. Sampel ikan kerapu sunu yang dianalisis berasal dari satu kelompok umur yang sama.

\section{Isolasi dan Purifikasi DNA}

DNA ikan kerapu sunu diisolasi dari bagian daging dengan menggunakan Nucleospin tissue kit (Macherey-Nagel). Tahapan isolasi dan purifikasi DNA sesuai dengan standar protokol dari produk tersebut. Kuantitas dan kemurnian DNA dari masing-masing sampel diukur dengan menggunakan spektrofotometer pada panjang gelombang $260 \mathrm{~nm}$ dan $280 \mathrm{~nm}$. Kemurnian DNA ditetapkan berdasarkan nilai rasio $A_{260} / A_{280}$ sekitar 1,8- 2,0 (Sambrook et al., 1989).

\section{Analisis Marker Gen dengan Primer Mikrosatelit}

Ikan kerapu sunu hasil seleksi fenotipik (ukuran kecil dan besar) selanjutnya dianalisis untuk mendapatkan marker gen. Reaksi PCR dilakukan terhadap semua sampel menggunakan enam set primer mikrosatelit (forward dan rever se). Susunan primer yang digunakan disajikan dalam Tabel 1. Setiap pasang primer diberi label dengan pewarna fluorescent (Fam; Hex dan Tet) pada forward primer yang bertujuan untuk mendeteksi secara terpisah alel dari setiap primer dalam satu sampel menggunakan mesin (automatic sequencer). Amplifikasi telah dilakukan dalam $25 \mu \mathrm{L}$ volume reaksi yang mengandung 25 ng DNA template, $10 \mathrm{mM}$ primer, 10x Buffer, 2,5 mM dNTP, dan 0,5 unit Taq polymerase (MD-Bio). PCR mengikuti thermal cycling untuk 1 siklus $95^{\circ} \mathrm{C}$ selama 5 menit, dilanjutkan dengan 35 siklus selama 30 detik pada $94^{\circ} \mathrm{C}$, 30 detik pada $56^{\circ} \mathrm{C}$ dan 30 detik pada $72^{\circ} \mathrm{C}$, diikuti 1 siklus suhu extention akhir $72^{\circ} \mathrm{C}$ selama 5 menit. Untuk lokus PL- L5, kondisi PCR adalah sama dengan lokus PL- 03; PL- 04; PL- 08; dan $\mathrm{PL}-\mathrm{L} 4$ kecuali suhu annealing yaitu $60^{\circ} \mathrm{C}$, demikian juga untuk lokus PL- L12 menggunakan suhu annealing yang berbeda yaitu $50^{\circ} \mathrm{C}$. Hasil amplifikasi kemudian diseparasi menggunakan ABI 3100 Aviant Genetic Analyzer dan dilaksanakan di laboratorium Genetika Molekuler Balai Besar Penelitian Bioteknologi dan Pemuliaan Tanaman Hutan (BBPBPTH - Jogjakarta). Pada saat elektroforesis menggunakan genescan 400 HD (Rox) size standard sebagai marker ukuran untuk mendeterminasi ukuran alel. Produk PCR sebanyak 1- $2 \mu \mathrm{L}$ untuk masing- masing sampel dimasukkan dalam cover plate 96 reaction + $12 \mu \mathrm{L}$ (Genescan 400 HD dan formamide

Tabel 1. Susunan basa pada primer mikrosatelit (forward dan reverse) yang digunakan dalam analisis gen penanda tumbuh cepat

Table 1. Sequence of primer microsatellite (forward and reverse) used to analyse gen marker of fast growth

\begin{tabular}{|c|c|c|}
\hline $\begin{array}{l}\text { Nama primer } \\
\text { Primer name }\end{array}$ & $\begin{array}{l}\text { Pengulangan sequens } \\
\text { Repeat sequence }\end{array}$ & $\begin{array}{c}\text { Urutan Basa }\left(5^{\prime}-3^{\prime}\right) \\
\text { Sequence of Bases }\left(5^{\prime}-3^{\prime}\right)\end{array}$ \\
\hline \multirow[t]{2}{*}{ PL-03 } & $(\mathrm{CA}) 22$ & F : TTTGTAGTTCAGTTCAGAAGAGC \\
\hline & & R : AACTAAGGTTCAATCCAAGTCCAAT \\
\hline \multirow[t]{2}{*}{ PL-04 } & (CA)19....(TG)23 & F : GAAAGTAAAAATACAGAGACGGAGG \\
\hline & & R : TCAAATACATCССССТАТСТССА \\
\hline \multirow[t]{2}{*}{ PL-08 } & 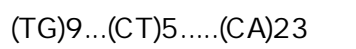 & F : ССТССТСTTCATTAGGGACATTTG \\
\hline & & R : GCCCAGCACCTACGCCAGTTTTAT \\
\hline \multirow[t]{2}{*}{ PL-L4 } & (GT)17 & F : АСССАТССАССТСССАТСССТАА \\
\hline & & R : TGTCTGCGTGCTCCAATCTATCT \\
\hline \multirow[t]{2}{*}{ PL-L5 } & $(\mathrm{CA}) 21$ & F : GCTGCCATTTATTTCGGCTTGA \\
\hline & & R : TTCAATTTAGCTCCACTTGCTT \\
\hline \multirow[t]{2}{*}{ PL-L12 } & (AC)19 & F : CTTGATGACTCGGGCTCCTTTC \\
\hline & & R : GTGTTTGGCAGGACCTTGAGTG \\
\hline
\end{tabular}


deionized) dan ditutup dengan MicroAmp ${ }^{\mathrm{TM}}$ Caps, kemudian di- vortex dan di-flushing. Selanjutnya dilakukan heat shock temperature dari suhu $95^{\circ} \mathrm{C}$ selama 2 menit ke suhu $4^{\circ} \mathrm{C}$ selama \pm 15 menit. Kemudian cover plate diletakkan dalam mesin ABI 3100 Aviant Genetic Analyzer. Hasil elektroforesis berupa peak kemudian dianalisis menggunakan software Genescan. Selanjutnya data fragmen tersebut dipindahkan ke program gene mapper 3.5 untuk menganalisis ukuran dari setiap fragmen tersebut. Hasil pembacaan ukuran fragmen setiap primer diinterpretasikan sebagai alel.

Untuk pembuktian dan validasi pengujian gen tumbuh cepat, maka selanjutnya dilakukan analisis lagi melalui sequencing. Dalam sequencing tersebut, dipersiapkan hasil amplifikasi PCR dan purifikasi amplicon. Hasil sequencing dianalisis menggunakan progam MEGA4 untuk mengetahui similaritas antar lokus mikrosatelit yang digunakan.

\section{HASIL DAN BAHASAN}

Dari enam set primer yang digunakan untuk analisis penanda gen tumbuh cepat dengan penanda mikrosatelit setelah diseparasi menggunakan ABI 3100 Aviant Genetic Analyzer dan dianalisis dengan perangkat lunak (software) gene mapper 3.5, nampaknya hanya 4 primer yaitu PL- 03; PL- 08; PL- L4; dan PL- L5 yang dapat menunjukkan polimorfisme fragmen gen yang bertanggung jawab pada tumbuh cepat, sedangkan primer PL- 04 dan PL- L12 tidak memberikan fragment yang polimorfisme.

Hasil yang diperoleh dari analisis mikro-satelit dengan primer PL- 03 pada kelompok ukuran besar yang terdeteksi ada $80 \%$ yang menunjukkan ukuran $370 \mathrm{bp}$, sedangkan pada ukuran kecil hanya sebesar 30\%(Gambar 1).

Pada lokus PL- 08 (Gambar 2), hasil polimorfisme DNA pada 342 bp menunjukkan

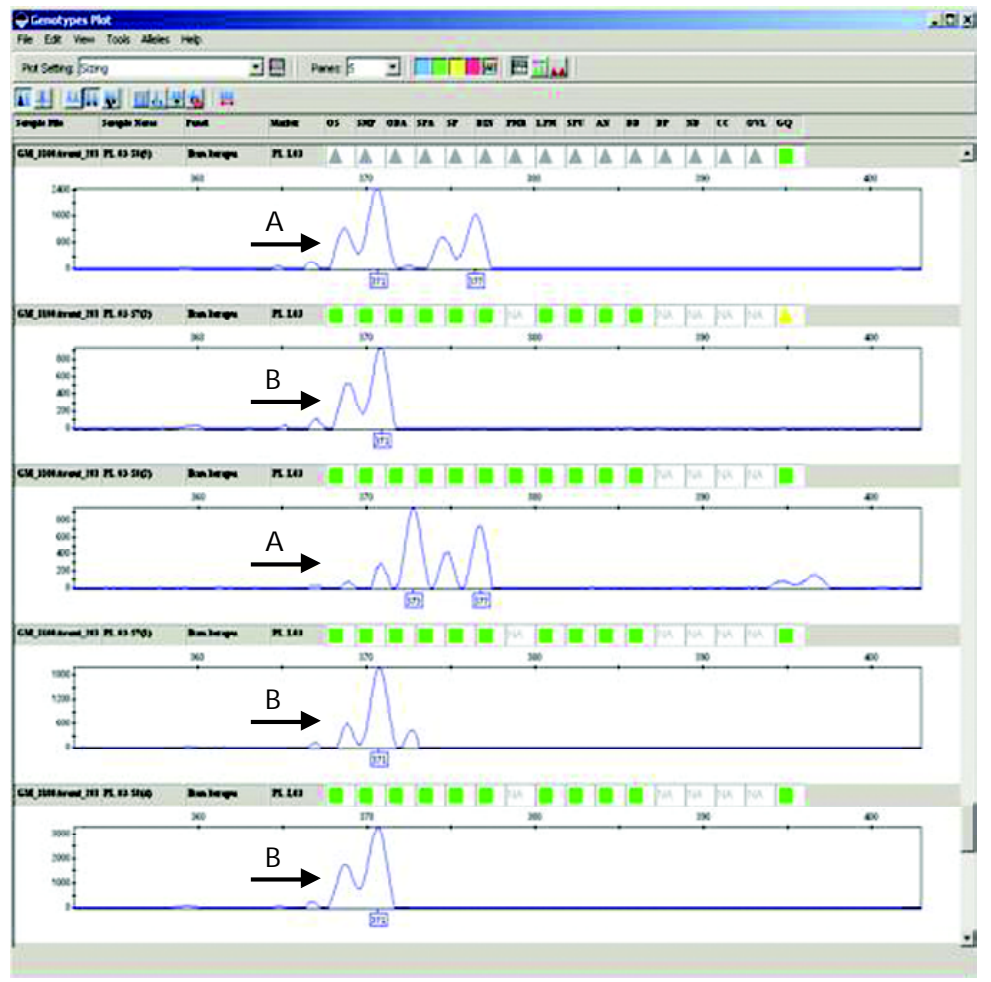

Gambar 1. Hasil separasi PCR produk ikan kerapu sunu, P. leopardus dengan primer PL- 03 menggunakan ABI 3100 Aviant Genetic Analyzer (A. ukuran besar; B. ukuran kecil)

Figure 1. Result of separation PCR product of coral trout grouper, P. leopardus with PL-03 primer using ABI 3100 Aviant Genetic Analyzer (A. big size; B. small size) 


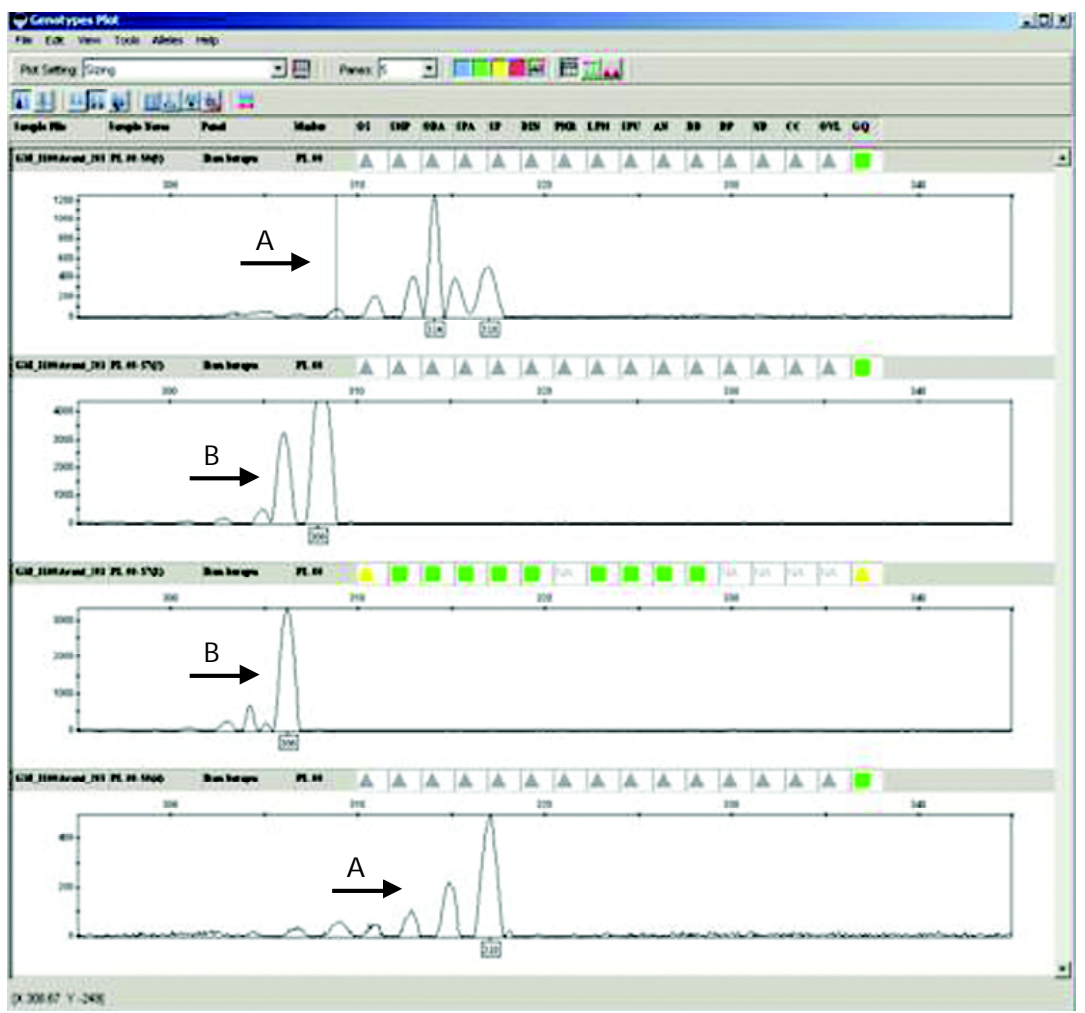

Gambar 2. Hasil separasi PCR produk ikan kerapu sunu, P. leopardus dengan primer PL- 08 menggunakan ABI 3100 Aviant Genetic Analyzer (A. ukuran besar; B. ukuran kecil)

Figure2. Result of separation PCR product of coral trout grouper, P. leopardus with PL-08 primer using ABI 3100 Aviant Genetic Analyzer (A. big size; B. small size)

$20 \%$ terdeteksi pada ikan kerapu sunu kelompok ukuran besar, sedangkan untuk ukuran kecil sebesar $80 \%$ terdeteksi pada ukuran $306 \mathrm{bp}$, sehingga lokus ini juga belum dapat digunakan sebagai penciri gen tumbuh cepat.

Pada primer PL- L4 juga nampak adanya separasi DNA untuk sampel kelompok ukuran besar dan kecil. Dari kelompok ukuran besar yang dianalisis ada $40 \%$ yang menunjukkan ukuran 315 bp; 50\%(305 bp) dan 20\%(317 bp), sedangkan pada ukuran kecil 40\% (305 bp dan 315 bp) dan 20\%(317 bp) (Gambar 3).

Pada lokus PL- L5 (Gambar 4), ikan kerapu sunu kelompok ukuran besar tidak dapat terseparasi pada fragment DNA dengan bobot molekul 341 bp secara jelas dan sempurna, hal ini terlihat dari "peak" yang muncul tidak seperti pada lokus PL- 03, sementara kelompok ukuran kecil hanya 20\% yang terdeteksi.
Dengan demikian nampaknya lokus tersebut juga belum dapat dijadikan penciri gen tumbuh cepat.

Pada lokus PL- 08; PL- 04; dan PL- L5, juga terlihat adanya fragmen yang tidak terdeteksi, hal ini karena munculnya band stutter yang disebabkan oleh slipp-strand mispairing selama proses PCR, dan band stutter akan cenderung berkurang dengan meningkatnya panjang unit mikrosatelit. Sehingga ketiga lokus tersebut masih belum dapat dijadikan lokus kuantitatif untuk mendeteksi secara akurat dari sifat gen yang bertanggung jawab pada tumbuh cepat. Dari keempat lokus tersebut di atas, nampaknya primer PL- 03 lebih baik dan akurat sebagai penciri gen tumbuh cepat pada ikan kerapu sunu karena dilihat dari polimorfisme fragment DNA pada $370 \mathrm{bp}$ sebanyak $80 \%$ sampel ukuran besar dapat terekspresi pada alel tersebut, sedangkan pada kelompok ukuran kecil hanya 30\% 


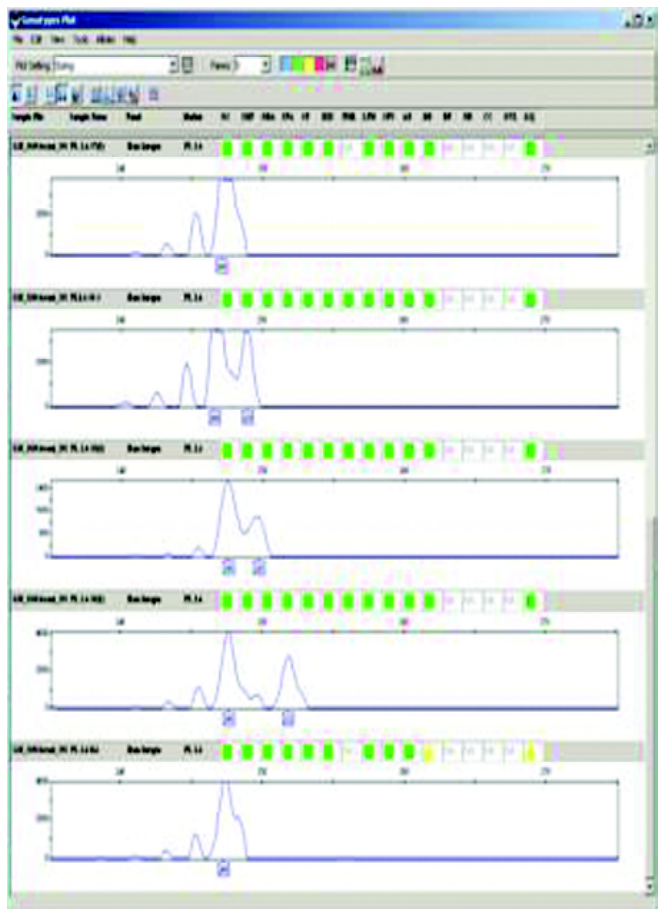

A

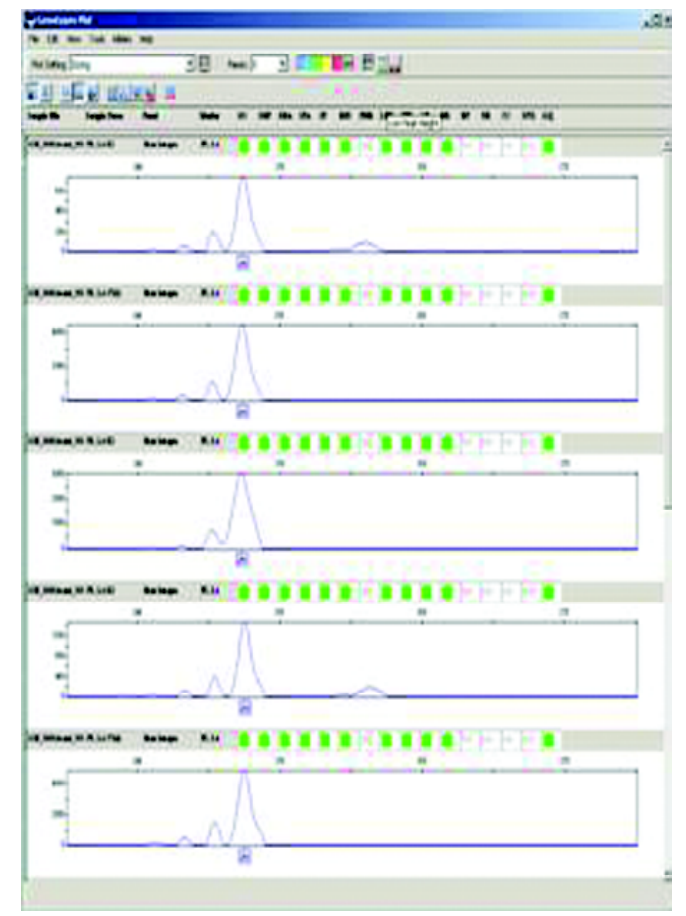

B

Gambar 3. Hasil separasi PCR produk ikan kerapu sunu, P. leopardus dengan primer PL- L4 menggunakan ABI 3100 Aviant Genetic Analyzer (A. ukuran besar; B. ukuran kecil)

Figure 3. Result of separation PCR product of coral trout grouper, P. leopardus with PL-L4 primer using ABI 3100 Aviant Genetic Analyzer (A. big size; B. small size)

Dengan menggunakan 4 penanda mikrosatelit saja, ternyata sudah dapat mendeteksi perbedaan genetik tumbuh cepat pada ikan kerapu sunu. Hal ini menunjukkan bahwa penanda mikrosatelit dapat digunakan untuk mendeteksi variasi alel yang tinggi. Selanjutnya Morgante \& Olivieri (1993), menyatakan bahwa penanda mikrosatelit yang memiliki nilai "Polymorphic Information Content" (PIC) 87 dapat digunakan untuk menyusun pemetaan QTL (Quantitative Trait Loci) dan dikembangkan untuk mencari penanda mikrosatelit yang berperan sebagai MAS (Marker Assisted Selection). Selain itu, penggunaan lokus mikrosatelit sebagai marker genetik dapat mengekspresikan sifat kodominan, mengikuti pola dasar keturunan Mendel, reproduktibilitas yang baik, menghasilkan alel yang terdeteksi dalam jumlah banyak dan mengekspresikan variasi genetik yang lebih tinggi (Mukherjee \& Nripendranath, 2009). Demikian juga Schloetterer \& Pemberton (1996) yang menyatakan bahwa mikrosatelit merupakan alat bantu yang sangat akurat untuk membedakan genotipe, evaluasi kemurnian turunan, pemetaan, dan seleksi genotipe untuk karakter yang diinginkan.

Untuk validasi dari lokus- lokus tersebut, dilakukan sequencing sampel ukuran besar. Hasil sequencing dari amplicon PCR kelompok besar untuk lokus PL- 03; PL- L4; dan PL- L5 setelah dianalisis dengan MEGA4 seperti tertera pada Tabel 2 .

Dari ketiga lokus tersebut terlihat bahwa lokus PL- 03 memberikan nilai kemiripan yang paling tinggi pada kelompok ukuran besar yaitu mencapai 99\% sehingga lokus PL-03 dapat dijadikan sebagai lokus kuantitatif untuk sifat tumbuh cepat pada ikan kerapu sunu. Demikian juga bila dilihat dari hasil kemiripan sequens total nucleotide DNA ikan kerapu sunu kelompok ukuran besar menunjukkan nilai kemiripan yang tinggi dari lima sampel yang di sequensing (Tabel 3). 


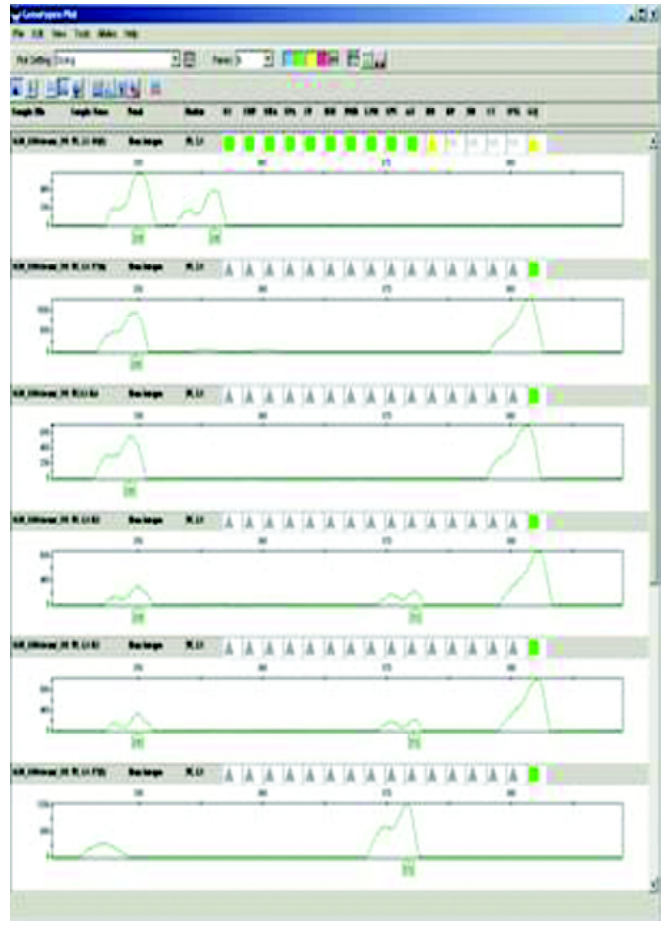

A

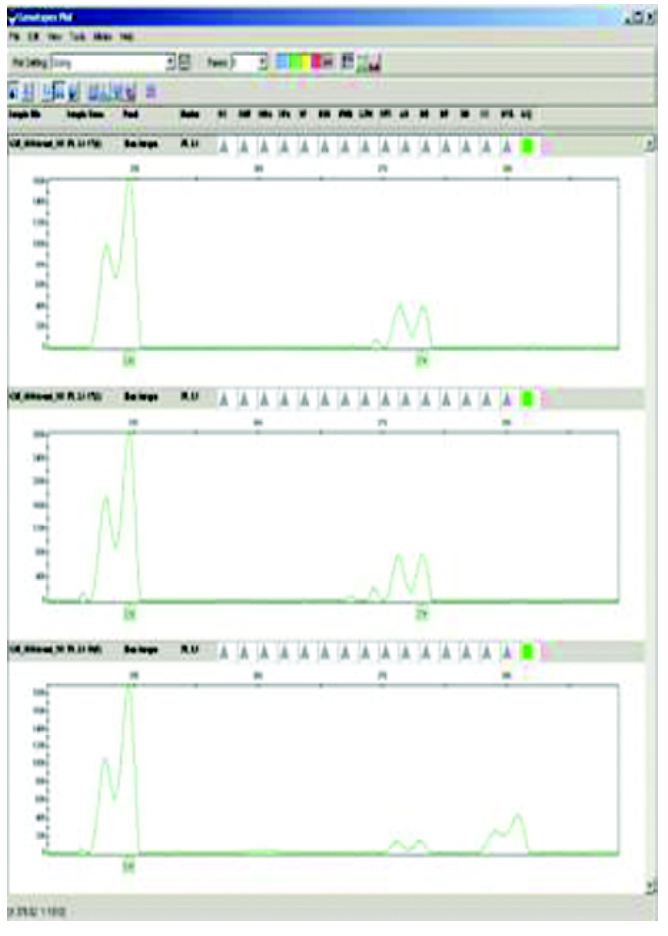

B

Gambar 4. Hasil separasi PCR produk ikan kerapu sunu, P. leopardus dengan primer PL- L5 menggunakan ABI 3100 Aviant Genetic Analyzer (A. ukuran besar; B. ukuran kecil)

Figure4. Result of separation PCR product of coral trout grouper, P. leopardus with PL-L5 primer using ABI 3100 Aviant Genetic Analyzer(A. big size; B. small size)

Tabel 2. Hasil similaritas pada ikan kerapu sunu, P. leopardus kelompok ukuran besar dengan 3 lokus mikrosatelit

Table2. Result of similarity on big size of coral trout grouper, P. leopardus with 3 locus microsatellite

\begin{tabular}{|c|c|c|c|c|}
\hline $\begin{array}{c}\text { Aksesi } \\
\text { Accession }\end{array}$ & $\begin{array}{c}\text { Deskripsi } \\
\text { Description }\end{array}$ & $\begin{array}{c}\text { Nilai } \\
\text { maksimum } \\
\text { Maximum } \\
\text { score }\end{array}$ & $\begin{array}{l}\text { Nilai total } \\
\text { Total score }\end{array}$ & $\begin{array}{c}\text { Tingkat } \\
\text { kemiripan } \\
\text { Similarity } \\
\text { (\%) }\end{array}$ \\
\hline gi|254679483|FJ548641.1 & $\begin{array}{l}\text { Plectropomus leopardus } \\
\text { clone PL-03 microsatellite } \\
\text { sequence }\end{array}$ & 562 & 5549 & 99 \\
\hline gi|254679490|FJ549858.2 & $\begin{array}{l}\text { Plectropomus leopardus } \\
\text { clone PL-L5 mic rosatellite } \\
\text { sequence }\end{array}$ & 492 & 2424 & 85 \\
\hline gi|253879959|6325758.1 & $\begin{array}{l}\text { Plectropomus leopardus } \\
\text { clone PL-L4 mic rosatellite } \\
\text { sequence }\end{array}$ & 351 & 3049 & 90 \\
\hline
\end{tabular}


Tabel 3. Hasil tingkat kemiripan sequens total nucleotide DNA ikan kerapu sunu, P. leopardus kelompok ukuran besar pada GenBank dengan nomor aksesi yang sama

Table3. Similarity sequens of total DNA nucleotide on big size coral trout grouper, P. leopardus in GenBank with same accession number

\begin{tabular}{ccccc}
\hline $\begin{array}{c}\text { Aksesi } \\
\text { Accesion }\end{array}$ & $\begin{array}{c}\text { Deskripsi } \\
\text { Description }\end{array}$ & $\begin{array}{c}\text { Nilai maksimum } \\
\text { Maxim um score }\end{array}$ & $\begin{array}{c}\text { Tingkat } \\
\text { Notai total score }\end{array}$ & $\begin{array}{c}\text { Timilarity } \\
\text { kemiripan } \\
\text { Sim }\end{array}$ \\
\hline F5548641.1 & $8-1$ & 311 & 314 & 99 \\
F5548641.1 & $8-5$ & 304 & 306 & 99 \\
F5548641.1 & $7-1$ & 309 & 314 & 98 \\
F5548641.1 & $7-4$ & 305 & 309 & 99 \\
F5548641.1 & $7-5$ & 301 & 305 & 99 \\
\hline
\end{tabular}

\section{KESIMPULAN}

- Penggunaan penanda mikrosatelit untuk penciri gen tumbuh cepat pada ikan kerapu sunu untuk seleksi diperoleh pada berat molekul 370 bp dengan primer PL- 03.

- Primer PL- 03 dapat dijadikan lokus kuantitatif untuk tumbuh cepat dengan adanya prediksi karakter fenotip tumbuh cepat sebanyak $80 \%$

- Hasil sequencing untuk validasi ketiga lokus primer menunjukkan nilai kemiripan 99\% pada lokus PL- 03.

\section{SARAN}

Penciri gen tumbuh cepat dengan penanda mikrosatelit pada lokus PL- 03 perlu diaplikasikan lebih Ianjut dalam seleksi calon induk ikan kerapu sunu.

\section{UCAPAN TERIMA KASIH}

Ucapan terima kasih kami sampaikan kepada semua teknisi dan analis Laboratorium Bioteknologi Balai Besar Penelitian dan Pengembangan Budidaya Laut, Gondol yang telah membantu dalam pelaksanaan penelitian ini, serta teman-teman di Laboratorium Genetika Molekuler Balai Besar Penelitian Bioteknologi dan Pemuliaan Tanaman Hutan (BBPBPTH - Jogjakarta) yang sudah membantu dalam menganalisis mikrosatelit.

\section{DAFTAR ACUAN}

Appleyard, S.A., Renwick, J.L., \& Mather, P.B. 2001. Individual Heterozygosity Levels and Relative Growth Performance in Oreochromis niloticus (L.) Cultured under Fijian Conditions. Aquaculture Research, 32: 287- 296.

Benzie, J.A.H., Kenway, M., \&Trott, L. 1997. Estimates for The Heritability of Size in Juvenile P. monodon from Half- sib Mattings. Aquaculture, 152: 49- 53.

Bierne, N., Beuzart, I., Vonau, V., Bonhomme, F., \& Bédier, E. 2000. Microsatellite- Associated Heterosis in Hatchery- Propagated Stocks of the Shrimp Penaeus stylirostris. Aquaculture, 184(3-4): 203- 219.

Del Rio- Portilla, M.A. \& Beaumont, A.R. 2000. Larval Growth, Juvenile Size and Heterozigosity in Laboratory Reared Mussel (Mytilus edulis). Journal of Experimental Marine Biology and Ecology, 254: 1- 17.

Fishback, A.G., Danzman, R.G., Sakamoto, T., \& Ferguson, M.M. 1999. Optimization of Semiautomated Microsatellite Multiplex Polymerase Chain Reaction Systems for Rainbow Trout (Oncorhynchus mykiss). Aquaculture, 172: 247- 254.

Hancock, J.M. 1999. Microsatellite and oyher Simple Sequence: Genomic Context and Mutational Mechanisms. In Goldstein, D.B. and Schlottere, C. (Eds.). Microsatellites: Evolution and Applications. Oxford University Press.

Morgante, M. \& Olivieri, A.M. 1993. Amplified microsatellites as Markers in Plant Genetics. Plant Journal, 3: 175- 182.

Mukherjee, K. \& Nripendranath, M. 2009. A Microsatellite DNA Marker Devekoped for Identifying Disease- resistant Population 
of Giant Black Tiger Shrimp, Penaeus monodon. Journal of The World Aquaculture Society, 40(2): 274- 280.

Sambrook, J., Fritsh, E.F., \& Maniatis, T. 1989. Molecular cloning. Cold Spring Harbor Laboratory Press, New York, p. 568- 500.

Sbordoni, V., De Mattthaeis, E., CobolliSbordoni, M., La Rosa, G., \& Mattoccia, M. 1987. Bottleneck Effects and The Depression of Genetic Variability in Hatchery Stocks of Penaeus japonicus (Crustacea: Decapoda). Aquaculture, 57: 239- 251.

Schloetterer, C. \& Pemberton, J. 1996. The Use of Microsatellite for Genetics Analysis of
Natural Population. Paper on European Union Meeting "Molecular Tools for Biodiversity. December $14^{\text {th }}-18^{\text {th }} 1996$, Vienna.

Slettan, A., Olsaker, I., \& Lie, O. 1993. Isolation and Characterization of Variable (GT)n Repetitive Sequences from Atlantic Salmon, Salmo-salar L. Anim Genet, 24: 195- 197.

Xiong Ding, S., Zeng, H.S., Wang, Y., Pan, Y., \& Feng Shi, X. 2009. Characterization of eight polymorphic microsatellite loci for the leopard coral grouper (Plectropomus leopardus). Molecular Ecology Resources. Blackwell Publishing Ltd. 